\title{
축소모형실험을 이용한 공동지반에서의 터널 거동특성 \\ Behaviour Characteristics of Tunnel in the Cavity Ground by using Scale Model Tests
}

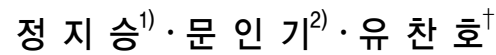 \\ Jeeseung Chung $\cdot$ Innki Moon $\cdot$ Chanho Yoo
}

Received: October 23 ${ }^{\text {rd }}, 2013$; Revised: November $13^{\text {th }}, 2013$; Accepted: November $21^{\text {st }}, 2013$

\begin{abstract}
As construction for road and train tunnel is increasing, various geotechnical conditions can be faced during the construction stage. Especially, if the tunnel is located in limestone area, the cavity is mostly to locate in tunnel planning location. One or some cavities which can be harmful for tunnel safety are predicted. Hence, this study was fulfilled to confirm the influence between tunnel and cavity using laboratory scale down model test and numerical analysis. The scale down model test was carried out to confirm the failure load of the model ground about the interval length of cavity and tunnel and to analyze behaviour characteristics of the model ground on the cavity shape. From the model test result, the failure load decrease in accordance with decreasing of interval length between cavity and tunnel within $0.5 \mathrm{D}$. The numerical analyses were carried out for verification about scale down model test. From the numerical analysis result, tunnel safety decreases in the case of the interval between cavity and tunnel within $0.5 \mathrm{D}$.
\end{abstract}

Keywords : Behaviour characteristics, Cavity, Failure load, Scale down test, Tunnel

요 지: 도로 및 철도의 터널 공사가 증가함에 따라 공사 시에 다양한 지반조건에서 터널 공사 단계를 진행하고 있다. 특히, 석회암 지역에서 터널 공사를 진행하게 되는 경우에는 대부분의 공동이 터널 계획구간에 존재하고 있는 실정이다. 하나 또는 그 이상의 공동은 터널의 안정성을 저하하는 것으로 예상된다. 따라서, 본 연구에서는 터널과 공동과의 상호 영향을 알아보고자 실내 모형 축소실험과 수치해석을 시행하였다. 실내모형실험은 터널과 공동 간의 거리에 따른 모형지반의 파괴하중을 확인하였고, 공동의 형 상에 따른 파괴하중을 확인하였다. 실내모형실험결과 파괴하중은 공동과 터널 간의 거리가 $0.5 \mathrm{D}$ 이내로 감소함에 따라서 파괴하중 역시 감소하는 것으로 나타났다. 수치해석은 모형실험의 검증을 위해 시행하였으며, 실내모형실험과 동일하게 터널과 공동 간의 거리가 $0.5 \mathrm{D}$ 이내로 근접하는 경우 터널의 안정성이 저하되는 것으로 확인되었다.

주요어 : 거동특성, 공동, 파괴하중, 축소모형실험, 터널

\section{1. 서 론}

지반 내에 터널을 굴착하면 필연적으로 지반손실을 발생 시키므로 터널 주변 지반에서 소성 영역이 확장되며 지반 내 초기 응력의 평형상태가 파괴되어 응력재분배 현상이 일 어나고, 이 영향으로 인해 터널 및 주변 지반은 변형하게 된 다. 이때, 터널 주변에 과도한 응력과 변형이 발생할 경우에 는 터널의 안정성이 심각한 영향을 받을 수 있다. 따라서 터 널은 석회암 공동이 분포하는 카르스트 지역에서 계획하는 경우 응력의 분포가 일반적이지 않기 때문에 공동의 영향을 반드시 고려하여야 하며, 공동 분포 시에도 터널의 안정성 은 확보하여야 한다.

공동이 분포하고 있는 석회암 암반 내에 터널을 굴착하
게 되면, 인접한 공동의 영향으로 인하여 터널의 응력 상태 및 변형 거동은 매우 복잡해진다. 즉, 석회암 암반에 터널 등의 지반구조물을 시공할 경우 터널과 인접한 석회암 공동 은 터널의 안정성에 중대한 영향을 미칠 수 있다.

석회암 공동이 터널의 안정성에 미치는 영향을 검토하기 위해 현지의 암반물성과 구조물의 형상 등을 상사율(Scale factor)로 환산하여 현지의 상태를 재현할 수 있는 축소모형 실험을 실시하였다. 이는 물리적이고 실제적인 실험으로써, 그 결과를 가시적으로 나타낼 수 있을 뿐 아니라, 수치해석 과 비교하는 경우 그 거동을 파악하는데 좋은 점이 있어, 본 연구에서는 공동 이격조건 및 분포형태에 따라 $\mathrm{CASE}$ 를 선 정하였다.

모형실험은 시험체 제작이 비교적 용이하고, 암반의 물

\footnotetext{
1) Dongyang University Department of Railroad Civil Engineering

2) Korea Development Co., Ltd. Civil Engineering Division

† Asin E\&C Co., Ltd. (Corresponding Author : randy2680@nate.com)
} 
성을 충실히 대변해 줄 수 있는 모래, 석고, 물 등의 혼합물 을 사용하였으며, 본 연구에서는 석회암 지대에 분포하는 공동영향에 따른 터널의 안정성을 확인하기 위해 공동과 터 널 간 이격 거리를 $0.25 \mathrm{D}, 0.50 \mathrm{D}, 1.00 \mathrm{D}$, Network 상태 분포 시로 가정하고, 공동이 없는 조건과 비교하여 모형실험을 실시함으로써 설계에 반영할 수 있는 신뢰성 높은 결과를 도출하고자 하였다.

또한, 모형실험과 수치해석방법으로 검증하여 터널의 거 동 예측 및 공동에 따른 영향범위 파악 등 공동이 터널에 미치는 영향을 검토하였다.

\section{2. 축소모형실험}

\section{1 실험 개요}

축소모형실험은 터널의 거동을 사전에 예측할 수 있는 효과적인 방법으로 많은 연구에 적용되어 왔다. Hwang et al.(2005) 및 Jang et al.(2006)은 병설터널 굴착 시 필라의 보강을 고려한 안정성 평가기법으로 축소모형실험을 이용 하였다. Baek et al.(2009) 및 Han et al.(2009)은 축소모형실 험을 통해 근접 병설터널에 대한 붕괴 인자 민감도 분석을 시행하였다.

축소모형실험에 앞서 우선 적합한 모형지반재료를 선정 하기 위하여 선정된 모형지반재료의 배합비를 결정하여 상 사율을 고려한 실제 지반의 강도를 모사하였다. 축소모형실 험은 공동조건이 터널 변형 거동에 미치는 영향을 조사하기 위하여 이격거리를 $0.25 \mathrm{D}, 0.50 \mathrm{D}, 1.00 \mathrm{D}$, Network 분포 시 및 공동이 없는 조건의 총 5 가지의 $\mathrm{CASE}$ 에 대해 모형실험 을 실시하였다. 축소모형실험을 진행하는 동안에는 터널 주 변의 변위를 계측하기 위해 디지털카메라 촬영을 통한 변위 및 파괴양상을 계측하였으며, 이에 따른 파괴하중을 계측하 는 방법으로 진행하였다. 또한, 수치해석 결과를 비교·분석 하여 터널의 영향범위를 분석하고, 모형지반의 내공변위를

Table 1. Scale decision of model tests

\begin{tabular}{c|c|c}
\hline Physical properties & Dimension & Scale factors \\
\hline Length & {$[\mathrm{L}]$} & $1 / 165$ \\
\hline Mass & {$[\mathrm{M}]$} & $1 / 7.47 \mathrm{e} 6$ \\
\hline Density & {$[\mathrm{ML}-3]$} & $1 / 1.643$ \\
\hline Strength & {$[\mathrm{ML}-1 \mathrm{~T}-2]$} & $1 / 272$ \\
\hline
\end{tabular}

예측하는 등 모형실험의 적정성을 검증토록 하였다.

\section{2 축소모형지반의 결정}

\subsection{1 축소율의 결정}

자연상태 암반의 변형 거동을 파악하기 위하여 축소모형 실험을 실시할 때 현장성을 충분히 재현할 수 있도록 하기 위해서는, 현장의 모든 제반요소에 대한 차원해석을 실시하 여 축소율을 산정하고 이에 따른 적합한 모형재료를 사용하 여 축소모형을 제작하여야 한다. Kim et al.(2006)은 축소모 형실험을 위해 길이, 질량 등에 대한 상사율을 결정하여 모 형실험을 수행한 바 있으며, 본 연구에서도 동일하게 항목 별로 축소율을 결정하여 모형실험을 수행하였다. 결정된 축 소율은 Table 1 및 Fig. 1과 같다.

\subsection{2 모형지반재료 선정 및 지반조건}

본 연구에서는 모래, 석고, 물 등의 혼합물을 사용하여 모 형지반을 조성하였으며, 모형지반으로 사용된 모래는 표준 사(K.S.L. 5100)를 이용하였고, 석고의 경우에는 K.S.L. 9001 규격품을 이용하였다.

또한, 본 연구에서는 공동 유무 및 터널과의 이격거리에 따른 주변 지반의 변형 거동 및 전체지반의 저항력을 산정 하는 것이 주목적이기 때문에 모형지반은 강도를 중심으로 모형재료를 선정하였으며, 모형지반의 강도에 대한 상사율 을 고려하여 모래, 석고, 물의 배합비를 결정하고, 일정 시간 건조하여 모형지반의 단위중량을 만족도록 모형지반을 조 성하였다. 모형지반조건에 적용된 지반 강도정수는 Table 2 와 같다

\subsection{3 모형지반의 배합비 결정}

우선 모형지반의 배합비를 결정하기 위하여 모래 : 석고 : 물의 총 중량을 유지하고, 배합비를 변화시켜가며 실내시

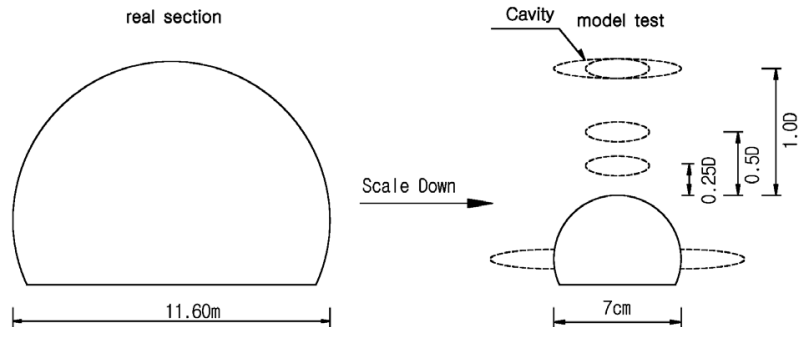

Fig. 1. Tunnel cross section of model tests

Table 2. Material properties of model tests

\begin{tabular}{c|c|c|c|c}
\hline Rock type & Unit weight, $\gamma\left(\mathrm{kN} / \mathrm{m}^{3}\right)$ & Elastic Modulus, Es(MPa) & Compression strength(MPa) & Poisson's ratio, $\nu$ \\
\hline Limestone & 23.0 & 400 & 70 & 0.28 \\
\hline
\end{tabular}


험을 시행하였으며, 석고와 물의 배합비 변화에 따른 압축 강도 및 변형계수의 상관관계를 분석한 결과 압축강도의 경 우 높은 상관성을 보이며, 변형계수는 상관성이 비교적 낮 게 평가되었다.

축소모형실험 모형지반조건에 부합되기 위해서는 $0.26 \mathrm{MPa}$ 의 일축압축강도가 필요하므로, 모형지반조성을 위해 사용 되어야 하는 모래 : 석고 : 물의 혼합물은 상관식을 이용하 여 배합비를 결정하면 Table 3 과 같다.

\section{3 축소모형 실험방법}

\subsection{1 모형지반 조성 및 실험 종류}

본 연구에서 축소모형실험은 물리학적 상사법칙의 상사 비율인 약 $1 / 165$ 에 해당하는 크기로, 축소모형실험에 이용 된 축소모형지반은 $600 \mathrm{~mm}($ 폭 $) \times 400 \mathrm{~mm}($ 높이 $) \times 100 \mathrm{~mm}$ (두 께)의 크기로 결정하였다. 재료를 교반장치에서 충분히 교
반한 후, 몰드 내에 서서히 주입하였으며, 몰드 내부에는 이 형제를 충분히 칠하여 모형지반의 추출 시 단면의 손상이 없도록 하였다.

본 연구에서는 공동의 형태 및 터널과의 간격을 이격 거 리별로 변화시켜가면서 축소모형실험을 시행하였다. 총 5 회의 축소모형실험을 시행하였으며, 본 연구에서 시행된 축 소모형실험 종류는 Table 4에 표기하였다. Table 4에 나타 낸 바와 같이 모형지반에서 터널의 크기는 $1 \mathrm{D}$ 약 $7.0 \mathrm{~cm}$ 로 결정하였고, 공동과 터널과의 상호작용 분석을 위해 터널직 경을 기준으로 $0.25 \mathrm{D}, 0.50 \mathrm{D}$ 및 $1.0 \mathrm{D}$ 이격되어 있는 조건으 로 모형실험 조건을 결정하였다.

\subsection{2 축소모형실험 방법}

본 연구에서의 축소모형실험의 재하방식은 기본적으로 변위제어방식으로 진행되었다. 축소모형실험은 미리 제작 한 모형지반을 모형터널시험기 안에 자립시킨 이후에 좌,

Table 3. Mixed ratio of model test materials

\begin{tabular}{c|c|c|c}
\hline In-situ rock density $\left(\mathrm{kN} / \mathrm{m}^{3}\right)$ & Model test material density $\left(\mathrm{kN} / \mathrm{m}^{3}\right)$ & Mixed ratio of model test materials & Remark \\
\hline \hline 23.0 & 14.0 & sand : gypsum $:$ water $=150: 50: 100$ & - \\
\hline
\end{tabular}

Table 4. Cases of model tests

\begin{tabular}{c|c|c|c}
\hline \multicolumn{2}{|c|}{ Classification } & Width of cavity \\
\hline \hline CASE 1 & No cavity & Remark \\
\hline CASE 2 & Distance of cavity : 0.25D & $0.5 \mathrm{D}$ \\
\hline CASE 3 & Distance of cavity : 0.5D & $0.5 \mathrm{D}$ \\
\hline CASE 4 & Distance of cavity : 1.0D & $0.5 \mathrm{D}$ \\
\hline CASE 5 & Network cavity & $1.0 \mathrm{D}$ \\
\hline
\end{tabular}

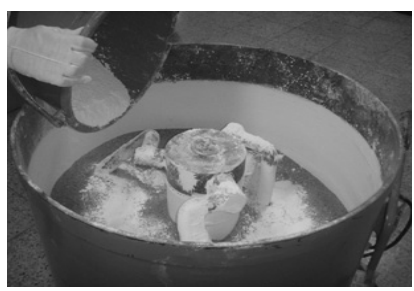

(a) Mixing of materials

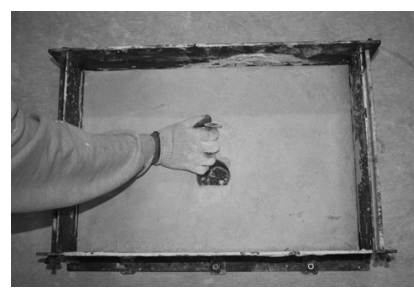

(d) Remove mold after drying

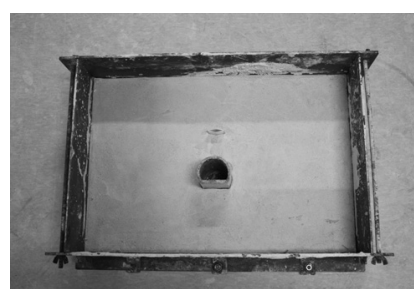

(b) Drying of model ground

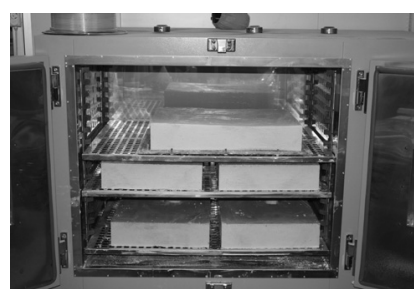

(e) Cure of model ground

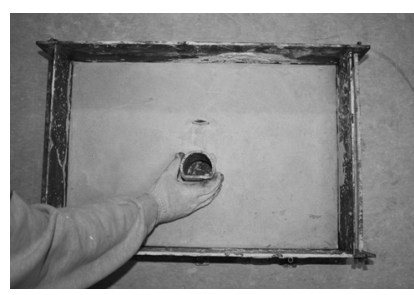

(c) Remove mold after drying

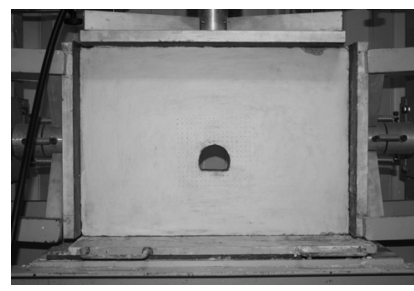

(f) Test and measure

Fig. 2. Process of model test 
우에 설치된 유압재하판을 이용하여 경계조건을 구속함과 동시에 측압을 작용하여 실제 응력 상태를 구현하는 것으로 시작하였다. 초기응력상태를 구현한 뒤, 모형지반 연직에 설치된 전기식 하중재하장치를 $1.25 \mathrm{~mm} / \mathrm{min}$ 의 속도로 재하 하여 모형지반이 파괴되는 시점까지 축소모형실험을 진행 하였다.

축소모형실험 시에는 연직방향으로 다이알게이지를 설치 하여 시간에 따른 변위량을 보다 정확하게 측정하였으며, 재 하판 위로 설치된 로드셀을 통해 지반에 작용하는 하중 값을 측정하여 모형지반의 응력-변형율 관계를 계측하였다.

완성된 모형시험체에 하중을 가하기 전에 모형지반의 변 형 거동 관찰을 위해 모형지반의 상부에 $1 \mathrm{~cm}$ 간격으로 계 측점을 표시하였다. 본 연구에서 시행된 축소모형실험의 과 정은 Fig. 2와 같다.

\section{3. 축소모형실험 결과}

\subsection{CASE 1(공동이 분포하지 않는 경우)}

터널 측벽부와 천단부에 균열이 발달하며, 터널 주변부로 아

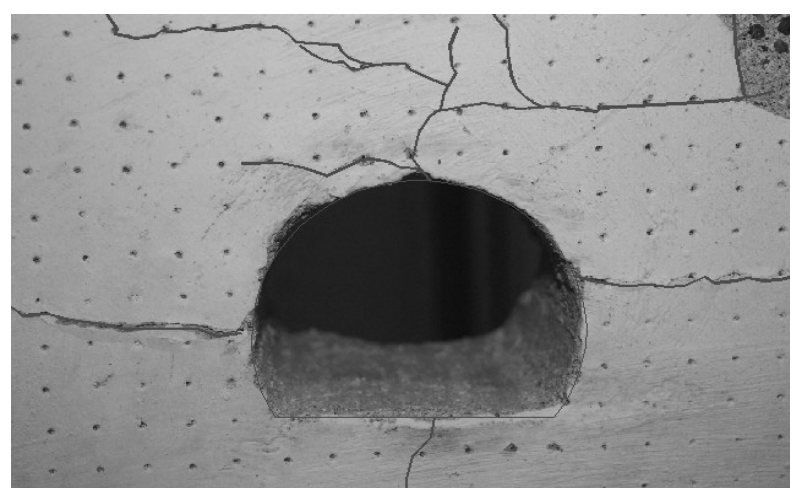

(a) Failure mode
칭 발생에 의한 변위 양상이 관측된다. 공동조건 없이 $250 \mathrm{kPa}$ 로 파괴하중이 가장 크며, 파괴하중이 $100 \%$ 선정되었다.

\subsection{CASE 2(공동이 상부 0.25D 이격 시)}

터널 측벽부 및 바닥부, 천단부에 균열이 발달하며, 하중 이 증가함에 따라 균열이 공동까지 연결되는 파괴 양상을 보인다. 상부 공동을 포함하여 터널 주변부로 아칭 발생에 의한 변위 양상이 관측되며, 파괴하중은 $215 \mathrm{kPa}$ 로 공동과 이격거리가 작아 $86 \%$ 로 감소한다.

\subsection{CASE 3(공동이 상부 0.5D 이격 시)}

터널 천단부에 미소균열 발생 후 균열은 측벽부 및 바닥 부로 발달하며, 하중이 증가함에 따라 공동상부까지 연결되 는 파괴양상을 보인다. 상부 공동을 포함하여 터널 주변부로 아칭 발생에 의한 변위 양상이 관측되며, 파괴하중은 $235 \mathrm{kPa}$ 로 공동과 이격거리의 영향으로 $94 \%$ 로 감소한다.

\subsection{CASE 4(공동이 상부 1.00D 이격 시)}

터널 바닥부에 미소균열 발생 후 균열은 천단부 및 측벽

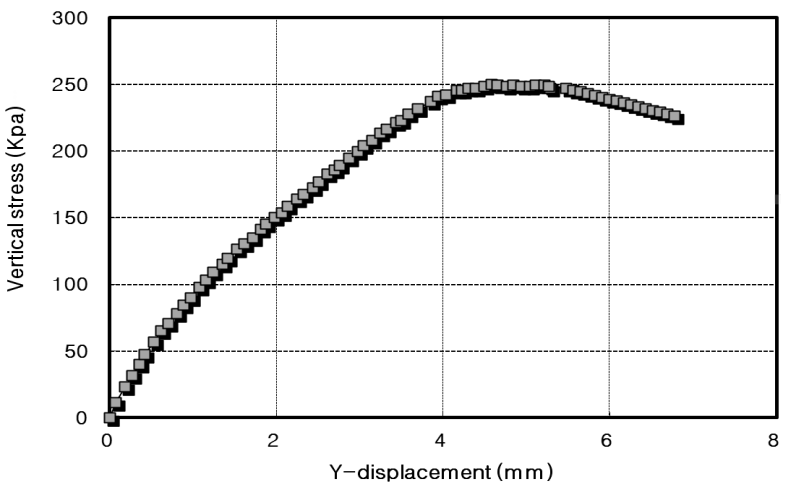

(b) p-y curve

Fig. 3. Result of model test case 1

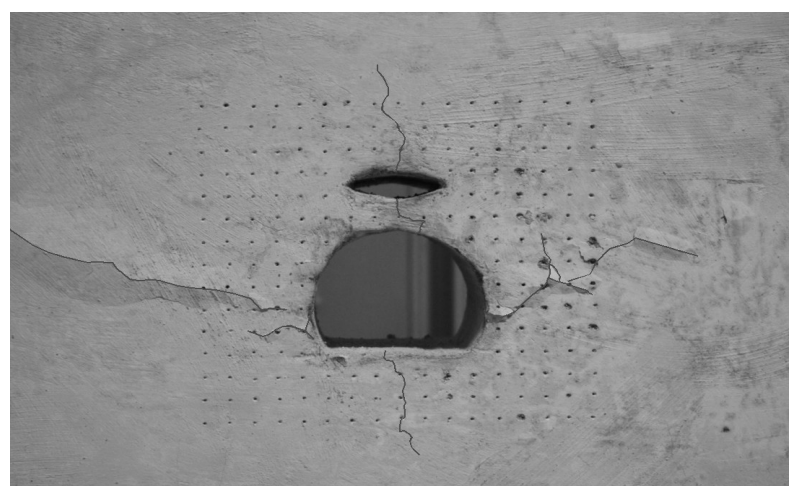

(a) Failure mode

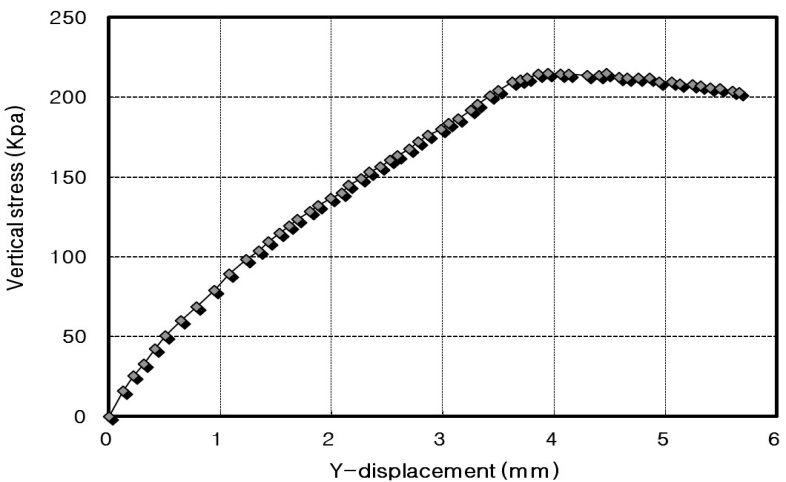

(b) $p-y$ curve

Fig. 4. Result of model test case 2 


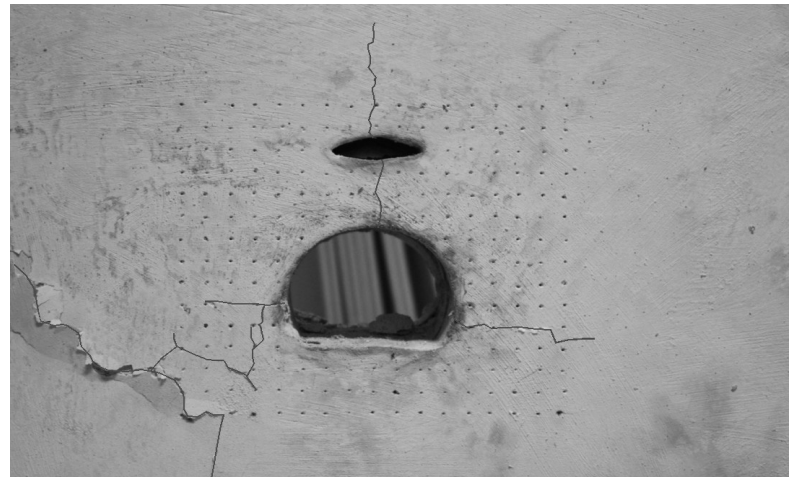

(a) Failure mode

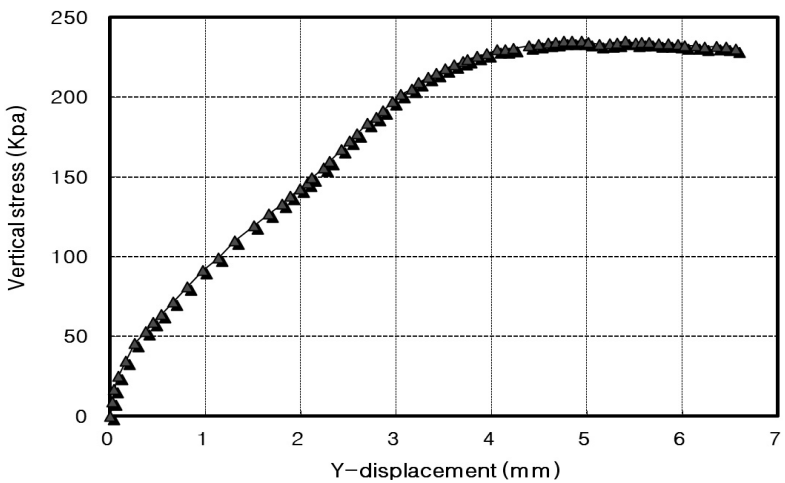

(b) p-y curve

Fig. 5. Result of model test case 3

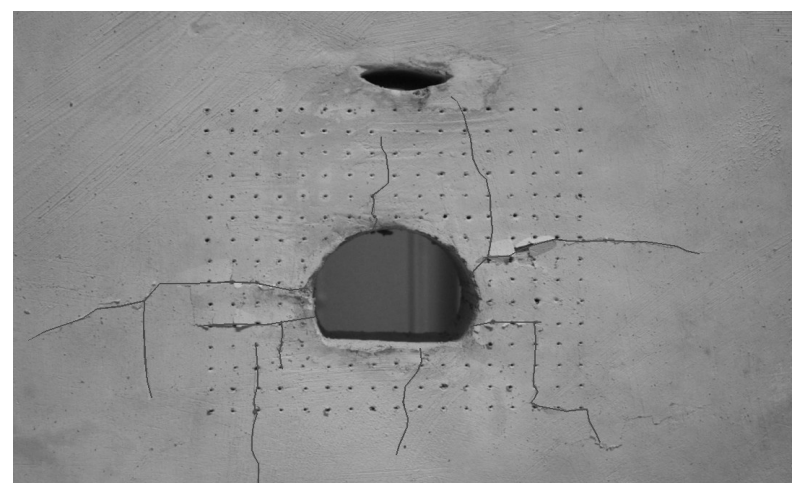

(a) Failure mode

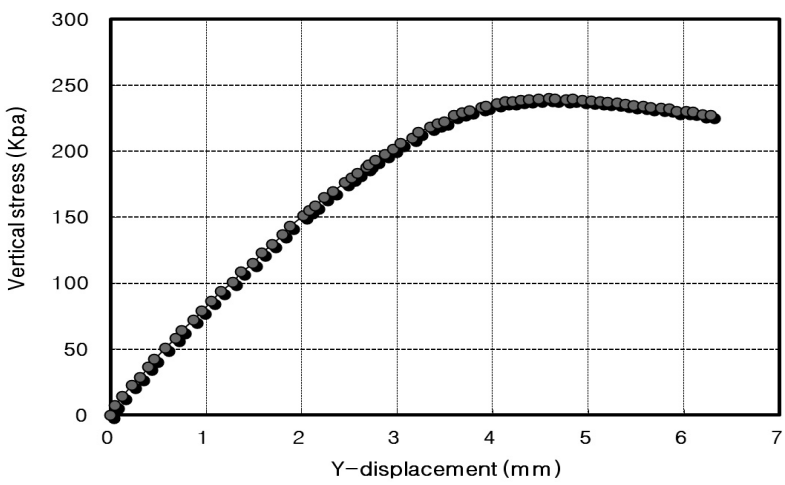

(b) p-y curve

Fig. 6. Result of model test case 4

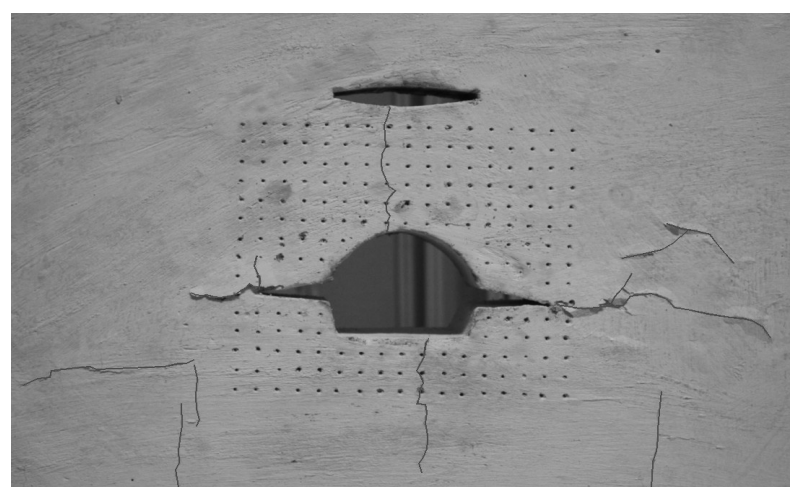

(a) Failure mode

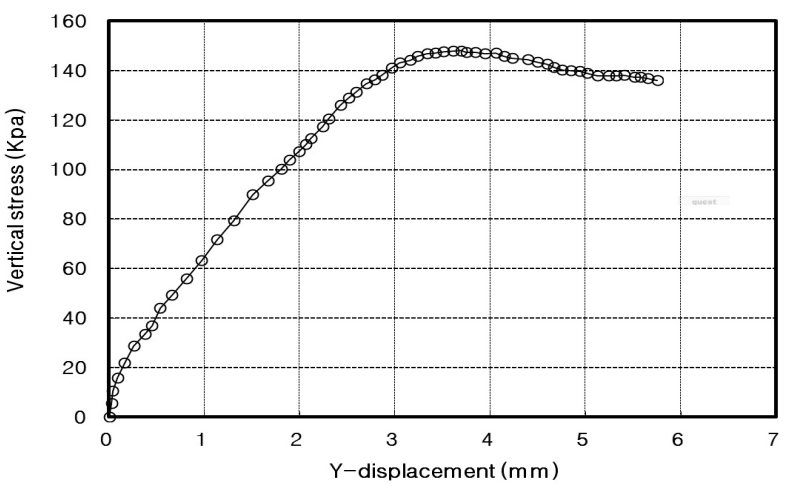

(b) p-y curve

Fig. 7. Result of model test case 5

부로 발달하며, 하중이 증가함에 따라 공동상부까지 연결되 는 파괴양상을 보인다. 상부 공동을 포함하여 터널 주변부로 아칭 발생에 의한 변위 양상이 관측되며, 파괴하중은 $240 \mathrm{kPa}$ 로 공동과 이격거리의 영향으로 $96 \%$ 로 감소한다.

\subsection{CASE 5(공동이 Network 분포 시)}

터널 측벽부 공동부에 미소균열 발생 후 균열은 천단부
및 측벽부로 발달하며, $80 \mathrm{kPa}$ 정도의 작은 하중조건에서도 균열발생이 관측되었다. 하중이 증가함에 따라 균열이 공동 상부까지 연결되는 파괴양상을 보이고, 상부 공동, 측벽 공 동을 포함하여 터널 주변부로 가장 큰 변위 양상이 관측된 다. 파괴하중은 $150 \mathrm{kPa}$ 로 측벽부 공동의 영향을 받아 $60 \%$ 로 가장 큰 감소를 보인다. 


\section{4. 수치해석을 퉁한 거둥분석}

\section{1 수치해석 개요}

본 연구에서는 모형지반의 재료가 취성재료 석고인 관계 로 터널 내부의 거동을 충분히 반영할 수 없을 것으로 판단 하여 실험에 대한 신뢰성 확보 및 터널 거동예측을 위하여 수치해석을 수행하였다. 터널 모형실험에서의 수치해석은 실험결과의 검증 및 변수분석을 위해 다양하게 적용된 바 있으며, 특히 Lee(2006)는 터널모형실험과 수치해석 결과를 비교하여 보고한 바 있다. 이에 본 연구에서는 수치해석을 통해 모형실험 결과를 검증하는 동시에 공동과의 상호작용 을 분석하는 자료로 활용하였다.

수치해석에서는 우선 모형지반을 그대로 격자 요소망으 로 모델링하여 역해석을 수행함으로써 모형지반의 지반강 도정수를 추정한 후, 이 결과를 이용하여 모형실험에 적용 된 하중이 작용할 때 터널 주변의 변위를 측정하는 방법으 로 진행하였다.

수치해석은 유한차분 수치해석 프로그램인 FLAC 프로 그램을 이용하였으며, 실제 축소실험에 사용된 모형지반과 동일하게 진행하였다.

\section{2 수치해석 조건}

실내모형실험의 경우 터널 주변 지반의 거동을 정밀하게 분석할 수 없으며, 실제 모형실험의 한계성을 보완하기 위 해 예비수치해석을 수행했다. 또한, 실험에 대한 신뢰성확 보를 위해 모형실험이 진행된 방법과 동일하게 모형실험에
적용된 하중이 작용할 때 터널 주변의 변위를 측정했다.

터널 주변의 공동은 $0.5 \mathrm{D}$ 의 폭으로 상부 $0.5 \sim 1.0 \mathrm{D}$ 이격 시와 Network 분포 상태에 대한 해석을 수행하였으며, 수치 해석에 적용된 모형지반 물성치는 역해석을 통해 모형실험 결과와 수치해석결과가 최대한 유사한 결과를 도출할 때까 지 시행착오법에 따라 결정하였다.

수치해석에서는 모형지반 조성 후 굴착을 추가로 모델 링하였으며, 굴착 이후에 축소모형실험과 동일하게 상부지 반에 하중을 재하하여 하중에 따른 변형의 관계를 평가하 였다.

하중이 재하하는 동안 모형 터널의 천단과 측벽에서 변 형 정도를 확인하였으며, 모형에 재하되는 하중은 단계별로 증가하는 것으로 가정하였고, 그 가정치는 다음과 같다.

\section{3 공동조건에 따른 영향범위 분석결과}

공동조건별 최대주응력 및 전단변형율에 따른 영향범위 를 분석하였으며, Network 상태 분포 시의 파괴하중을 고 려하여 동일한 하중조건인 $150 \mathrm{kPa}$ 인 조건에서의 최대주 응력도 및 전단변형율을 비교하여 터널의 영향범위를 분 석하였다.

\subsection{1 공동이 $0.25 \mathrm{D}$ 이격된 경우}

공동이 없는 조건에 비해 터널 영향범위가 공동부까지 전체적으로 확장되는 형태를 보이고 있으며, 공동과 터널의 이격거리가 $0.25 \mathrm{D}$ 로 매우 근접한 상태이므로, 터널과 공동 이 일체화 거동되는 불안정한 거동을 나타내는 것으로 검토 되었다.

Table 5. Material properties of numerical analysis

\begin{tabular}{c|c|c|c|c}
\hline Classification & Unit weight & Elastic Modulus & Cohesion & Friction \\
\hline \hline Model ground & $14.0 \mathrm{kN} / \mathrm{m}^{3}$ & $30 \mathrm{Mpa}$ & $20 \mathrm{kN}$ & 17 \\
\hline
\end{tabular}

Table 6. Load step in numerical analysis

\begin{tabular}{|c|c|c|c|c|c|c|c|c|c|c|}
\hline \multirow{2}{*}{ Classification } & Step 1 & Step 2 & Step 3 & Step 4 & Step 5 & Step 6 & Step 7 & Step 8 & Step 9 & Step 10 \\
\hline & Step 11 & Step 12 & Step 13 & Step 14 & Step 15 & - & - & - & - & - \\
\hline \multirow{2}{*}{ CASE 1} & $10 \mathrm{kPa}$ & $20 \mathrm{kPa}$ & $30 \mathrm{kPa}$ & $40 \mathrm{kPa}$ & $50 \mathrm{kPa}$ & $60 \mathrm{kPa}$ & $70 \mathrm{kPa}$ & $80 \mathrm{kPa}$ & $90 \mathrm{kPa}$ & $100 \mathrm{kPa}$ \\
\hline & $120 \mathrm{kPa}$ & $150 \mathrm{kPa}$ & $200 \mathrm{kPa}$ & $250 \mathrm{kPa}$ & - & - & - & - & - & - \\
\hline \multirow{2}{*}{ CASE 2} & $10 \mathrm{kPa}$ & $20 \mathrm{kPa}$ & $30 \mathrm{kPa}$ & $40 \mathrm{kPa}$ & $50 \mathrm{kPa}$ & $60 \mathrm{kPa}$ & $70 \mathrm{kPa}$ & $80 \mathrm{kPa}$ & $90 \mathrm{kPa}$ & $100 \mathrm{kPa}$ \\
\hline & $120 \mathrm{kPa}$ & $150 \mathrm{kPa}$ & $200 \mathrm{kPa}$ & $210 \mathrm{kPa}$ & - & - & - & - & - & - \\
\hline \multirow{2}{*}{ CASE 3} & $10 \mathrm{kPa}$ & $20 \mathrm{kPa}$ & $30 \mathrm{kPa}$ & $40 \mathrm{kPa}$ & $50 \mathrm{kPa}$ & $60 \mathrm{kPa}$ & $70 \mathrm{kPa}$ & $80 \mathrm{kPa}$ & $90 \mathrm{kPa}$ & $100 \mathrm{kPa}$ \\
\hline & $120 \mathrm{kPa}$ & $150 \mathrm{kPa}$ & $200 \mathrm{kPa}$ & $235 \mathrm{kPa}$ & - & - & - & - & - & - \\
\hline \multirow{2}{*}{ CASE 4} & $10 \mathrm{kPa}$ & $20 \mathrm{kPa}$ & $30 \mathrm{kPa}$ & $40 \mathrm{kPa}$ & $50 \mathrm{kPa}$ & $60 \mathrm{kPa}$ & $70 \mathrm{kPa}$ & $80 \mathrm{kPa}$ & $90 \mathrm{kPa}$ & $100 \mathrm{kPa}$ \\
\hline & $120 \mathrm{kPa}$ & $150 \mathrm{kPa}$ & $200 \mathrm{kPa}$ & $240 \mathrm{kPa}$ & - & - & - & - & - & - \\
\hline \multirow{2}{*}{ CASE 5} & $10 \mathrm{kPa}$ & $20 \mathrm{kPa}$ & $30 \mathrm{kPa}$ & $40 \mathrm{kPa}$ & $50 \mathrm{kPa}$ & $60 \mathrm{kPa}$ & $70 \mathrm{kPa}$ & $80 \mathrm{kPa}$ & $90 \mathrm{kPa}$ & $100 \mathrm{kPa}$ \\
\hline & $120 \mathrm{kPa}$ & $150 \mathrm{kPa}$ & - & - & - & - & - & - & - & - \\
\hline
\end{tabular}




\subsection{2 공동이 0.50D 이격된 경우}

공동이 없는 조건에 비해 터널 영향범위가 공동하부 및 측벽부로도 확장되는 형태를 보이고 있으며, 공동과 터널의 이격거리가 $0.50 \mathrm{D}$ 로 비교적 근접한 상태이나, 파괴하중은 공동이 없는 조건대비 $94 \%$ 정도로 비교적 양호한 것으로
검토되었다.

\subsection{3 공동이 1.00D 이격된 경우}

공동이 없는 조건에 비해 공동과 터널이 응력을 서로 분 담하는 양상을 보이며, 터널 영향범위가 공동부분 일부를

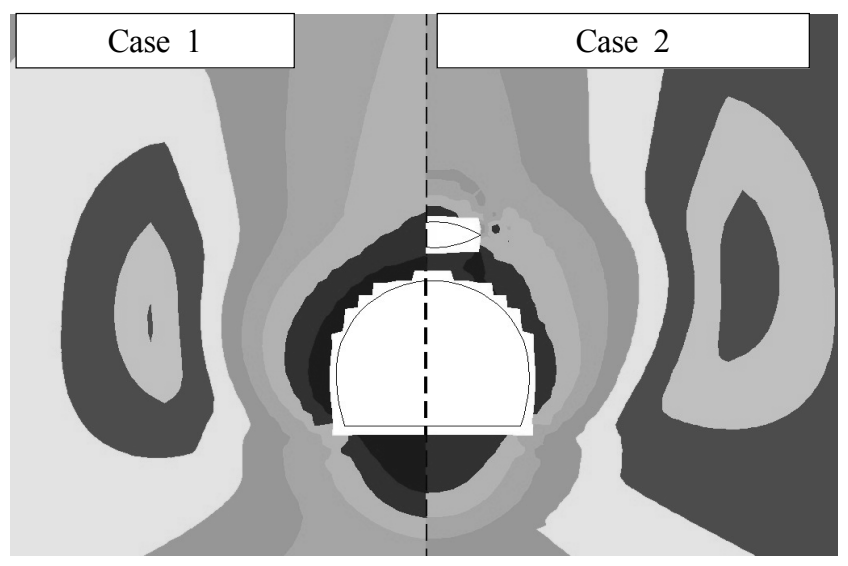

(a) Maximum principal stress

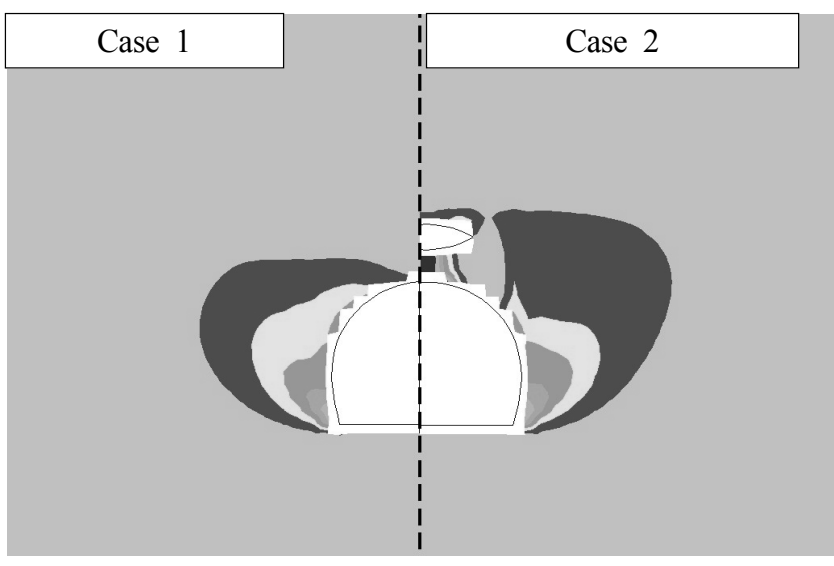

(b) Shear Strain

Fig. 8. Result of numerical analysis case 1 and 2

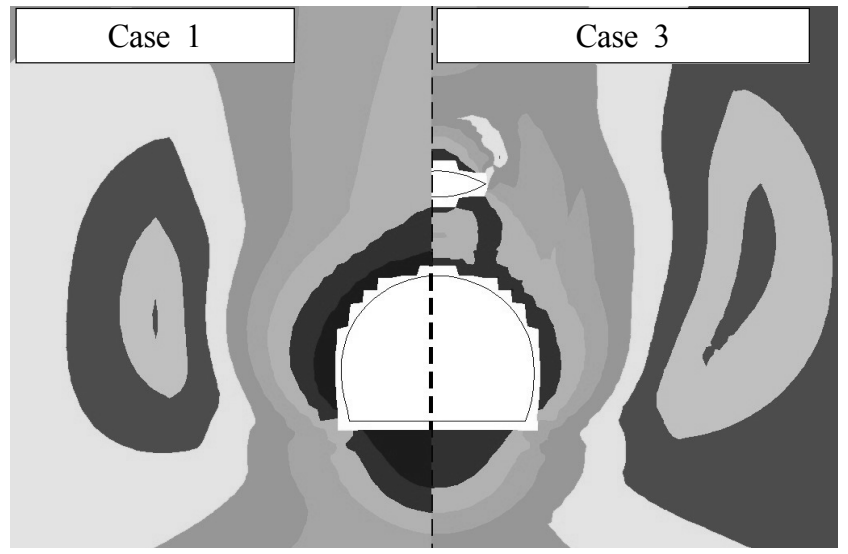

(a) Maximum principal stress

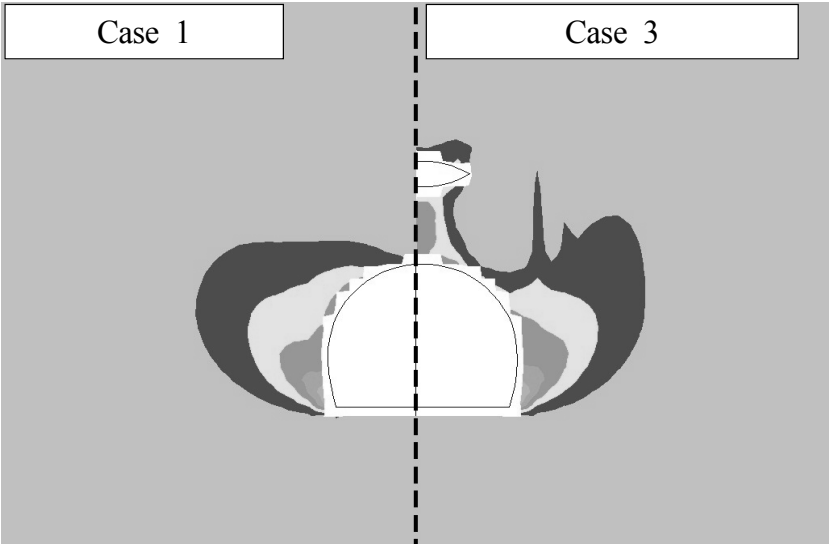

(b) Shear Strain

Fig. 9. Result of numerical analysis case 1 and 3

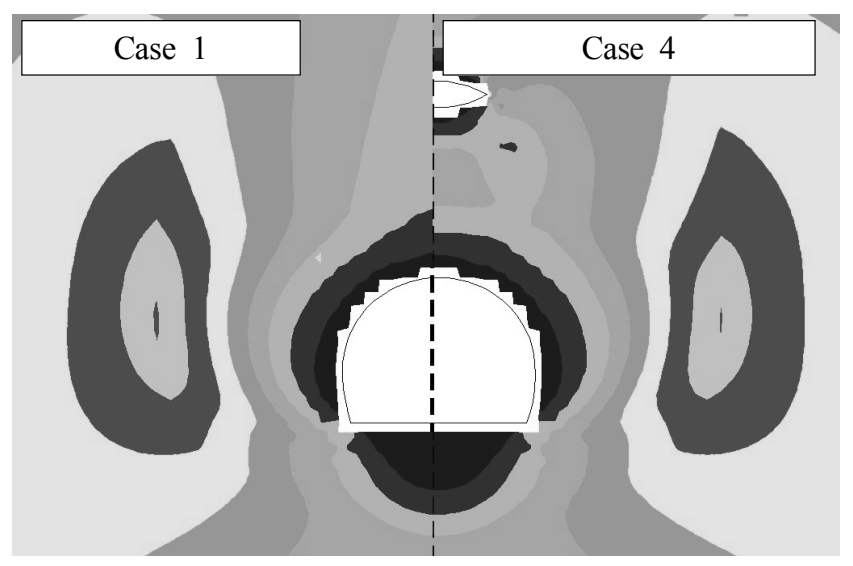

(a) Maximum principal stress

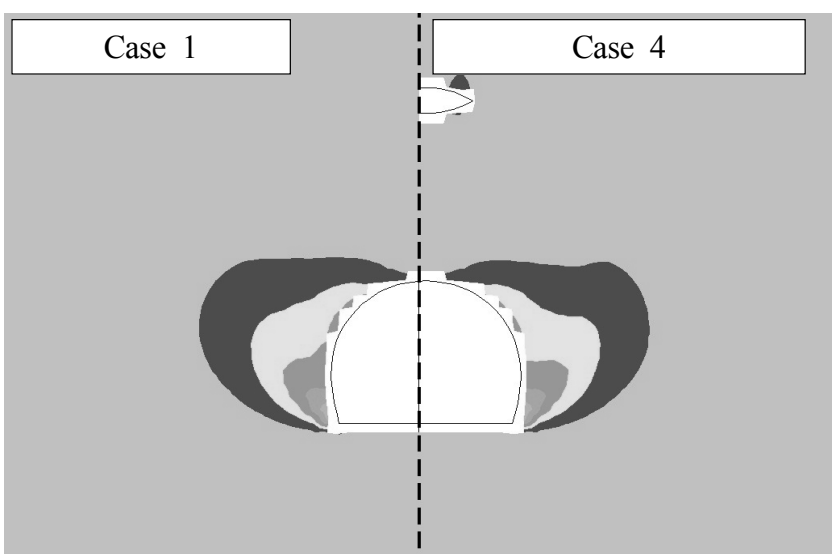

(b) Shear Strain

Fig. 10. Result of numerical analysis case 1 and 4 


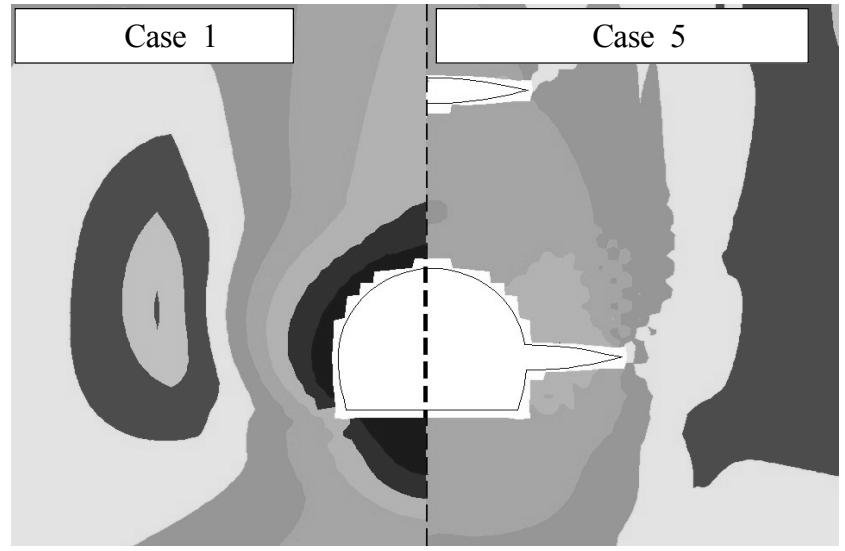

(a) Maximum principal stress

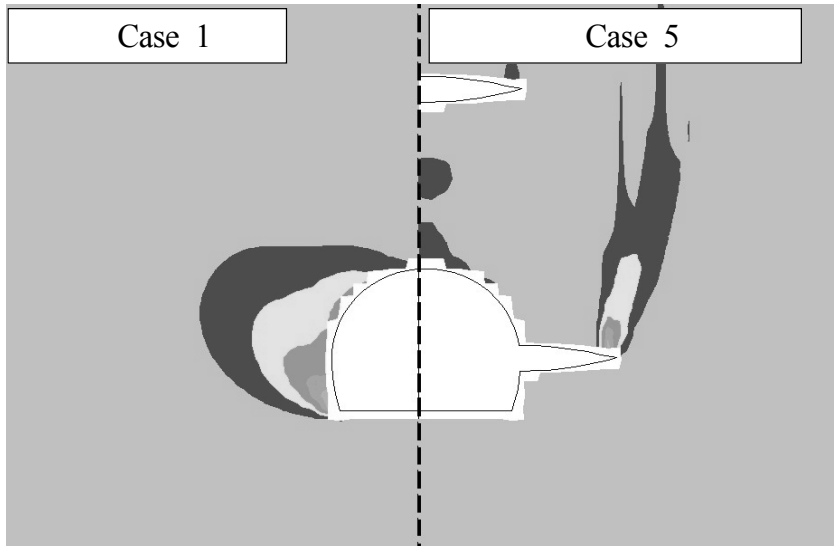

(b) Shear Strain

Fig. 11. Result of numerical analysis case 1 and 5

제외하면, 공동이 없는 조건과 매우 비슷한 형태를 나타낸 다. 또한, 공동과 터널의 이격거리가 $1.0 \mathrm{D}$ 로 이격된 영향에 서 파괴하중은 공동이 없는 조건대비 $96 \%$ 정도로 양호한 것으로 검토되었다.

\subsection{4 공동이 Network 상태 분포 시}

공동이 없는 조건에 비해 터널 영향범위가 좌우측 측벽 부의 공동 상부에서 상부로 전반적으로 크게 확장되는 형태 를 보이고 있으며, 공동과 접하고 있어 매우 불안정한 거동 을 나타낸다. 또한, 일체화 거동되는 불안정한 거동을 나타 내는 것으로 검토되었다.

또한, 파괴하중은 공동이 없는 조건대비 $60 \%$ 정도로, 작 은 하중조건에서도 변형이 관찰되는 등 안정성 측면에서는 매우 불량한 것으로 검토되었다.

\subsection{5 터널 영향범위 분석결과}

동일한 하중조건인 $150 \mathrm{kPa}$ 인 조건에서의 전단변형율을 를 비교·분석하여 터널의 영향범위를 분석하고 터널 영향 범위를 예상하면 Fig. 12와 같다.

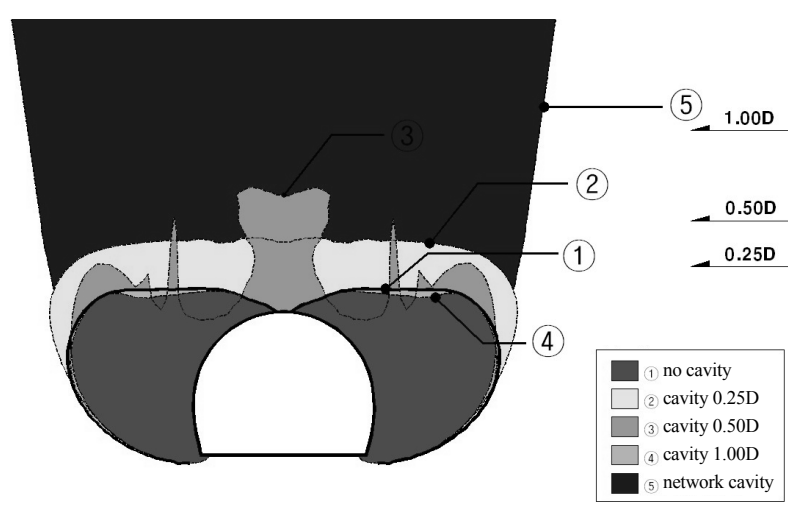

Fig. 12. Result of failure load on cavity condition

\section{4 공동조건에 따른 하중-변위 거동 분석결과}

공동조건별 모형실험결과 파괴하중은 $160 \mathrm{kPa} \sim 250 \mathrm{kPa}$ 로 계측되었으며, 모형실험결과를 토대로 하중-변위 거동을 분석하여 파괴하중에 따른 공동 영향범위를 분석하면 공동 이 Network 상태로 분포하는 경우 및 이격거리 $0.5 \mathrm{D}$ 이하 인 경우 공동 영향권 이내로, 터널의 안정성에 불리한 영향 을 미치는 것으로 판단된다.

\section{5. 결 론}

본 연구에서는 석회암 지대에 분포하는 공동영향에 따른 터널의 안정성을 확인하기 위해 축소모형시험을 수행하였 다. 모형실험은 공동과 터널간 이격거리를 $0.25 \mathrm{D}, 0.50 \mathrm{D}$, $1.00 \mathrm{D}$, Network 상태 분포 시로 가정하고, 공동이 없는 조 건과 비교하여 모형실험을 실시함으로써 설계에 반영할 수 있는 신뢰성 높은 결과를 도출하고자 하였다.

본 연구에서는 시험체 제작이 비교적 용이하고, 암반의 물성을 충실히 대변해 줄 수 있는 모래, 석고, 물 등의 혼합

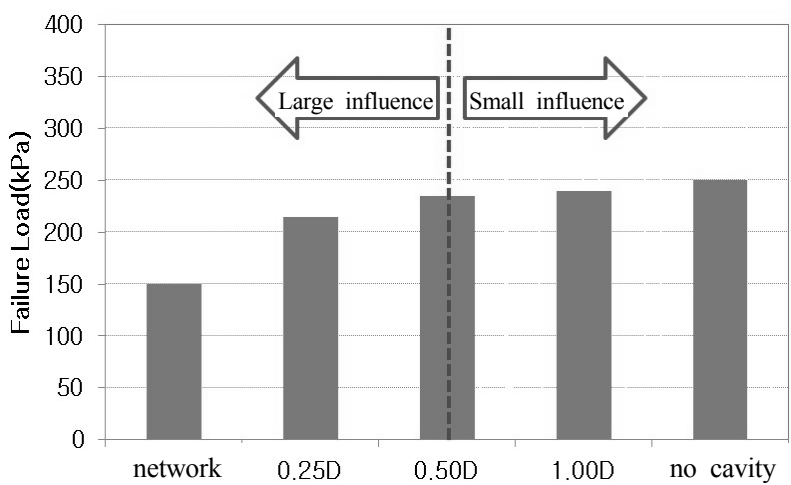

Fig. 13. Result of failure load on cavity condition 
지반을 조성하였으며, 본 연구를 통해 얻어지는 주요 내용

을 요약·정리하면 다음과 같다.

(1) 축소모형실험결과, 공동이 없는 경우 지반의 전체 저항 하중은 $250 \mathrm{kPa}$ 로 가장 큰 하중에 저항하는 것으로 평 가되었으며, Network 상태로 분포하는 경우 가장 작은 하중조건에서 파괴가 발생하고, 영향범위도 전반적으 로 크게 형성되어 안정성에 매우 불량한 것으로 평가되 었다.

(2) 공동과의 이격거리에 따른 파괴하중을 분석한 결과 $0.25 \mathrm{D}$ 이격된 경우에는 파괴하중이 $86 \%$ 정도로 감소하며, 영 향범위가 공동까지 확장되어 매우 불량한 것으로 평가 되었다. $0.50 \mathrm{D}$ 이격 시 파괴하중은 $94 \%, 1.0 \mathrm{D}$ 이격 시 $96 \%$ 로 $0.50 \mathrm{D}$ 이상 이격된 경우 파괴하중은 수렴하는 양상을 보이는 것으로 평가되었다.

(3) 공동조건에 따른 영향범위 분석결과, Network 상태 시 영향범위가 가장 크고, 공동과의 이격거리가 증가할수 록 영향범위는 감소하며, $1.0 \mathrm{D}$ 이격된 경우 공동이 없 는 조건과 거의 같은 영향범위를 나타내는 것으로 평가 되었다. 또한, 공동과 터널의 이격거리가 가까울수록 터 널 주변에서의 변위량도 많은 것으로 관찰되었다.
1. Baek, S. C., Jang, B. S., Lee, T. G., Lee, S. M. and Hwang, J. S. (2009), A study on the stability estimation procedure for reinforced pillar of twin tunnel, Journal of Korean Geo-environmental Society, Vol. 10, No. 7, pp. 81 91 (in Korean).

2. Han, Y. J., Shim, S. B., Choi, Y. K., Kim, G. H., Chang, O. S. and Kim H. T. (2009), The sensitivity analysis on failure parameter of adjacent twin tunnel using model tests, Korean Geotechnical Society Spring Conference, pp. 1214 1219 (in Korean).

3. Hwang, J. S., Kim, S. W., Bang, Y. K. and Kim H. T. (2005), Stability estimation method and analysis for pillar considering the reinforcement method, Korean Society of Civil Engineering Annual Conference, pp. 5571 5574 (in Korean).

4. Jang, B. S., Hwang, J. S., Ryu, J. W., Lee, Y. G. and Kim, H. T. (2006), Stability estimation method for pillar considering the reinforcement method during twin-tunnel excavation, Korean Geotechnical Society Spring Conference, pp. 980 987 (in Korean).

5. Kim, H. T., Park, J. Y. and Yoo, C. H. (2006), A study on optimal reinforcing type of precast retaining wall reinforced by micropiles, Journal of Korean Geotechnical Society, Vol. 22, No. 11, pp. 89 99 (in Korean).

6. Lee, Y. J. (2006), Comparison of shallow model tunnel test using image processing and numerical analysis, Journal of Korean Geotechnical Society, Vol. 22, No. 7, pp. 5 12 (in Korean). 